\title{
WHERE DOES THE XANGÔ LIVE? LOCATION FACTORS OF THE AFRICAN RELIGIOUS TERREIROS TO THE MARGINS OF ÁGUA FRIA RIVER - RECIFE (CENTURIES 19TH AND 20TH)
}

\author{
Bruno Maia Halley, \\ Geography Doctorate from UFF, and Research Associate of \\ Laboratory about Space Studies, Culture and Politics - LECgeo/UFPE, \\ E-mail: bhalleype@hotmail.com
}

\begin{abstract}
The text discusses the location factors of "terreiros" of Xangô in the city of Recife, in the context of the decade 1930, in an area adjacent to the city of Olinda, to the margins of Água Fria old river (current Channel Vasco da Gama-Peixinhos), tributary of the Beberibe river. Revisits thus within the North Zone of the city, the historical reasons and the geographical factors of the spatial concentration of centers of afro-religious worship on the banks of these water courses, that decisively influenced in the formation of the suburbs formerly located in the area known as Beberibe de Baixo and adjacencies, in the course of the end 19th century and first half of the 20th century. In light of this period are listed the african-religious leaders and their terreiros, cartographically represented along the river above-mentioned.
\end{abstract}

Keywords: Terreiros of Xangô; Água Fria River (Beberibe River); Territorial Formation; Surroundings; and Recife.

Resumo: O texto aborda os fatores de localização dos terreiros de Xangô na cidade do Recife, no contexto do decênio de 1930, numa área limítrofe ao município de Olinda, às margens do antigo rio Água Fria (atual Canal Vasco da Gama-Peixinhos), afluente do rio Beberibe. Resgata, assim, no âmbito da Zona Norte da cidade, as razões históricas e os fatores geográficos da concentração espacial dos centros de culto afro-religioso às margens destes cursos d'águas, que influenciaram decisivamente na formação dos arrabaldes outrora situados na zona conhecida como "Beberibe de Baixo" e adjacências, no transcorrer do final do século XIX e primeira metade do XX. À luz deste período, são enumerados os líderes afro-religiosos e seus terreiros, representados cartograficamente ao longo do rio supracitado.

Palavras-Chaves: Terreiros de Xangô; Rio Água Fria (Rio Beberibe); Formação Territorial; Arrabaldes; e Recife.

Resumen: El texto analiza los factores de localización de los "terreiros" de Xangô en Recife, en el contexto de la década de 1930, en un área adyacente a la ciudad de Olinda, en las orillas del antiguo río Agua Fría (hoy Canal Vasco da Gama-Peixinhos), un tributario del río Beberibe. Rescata así dentro de la Zona Norte de la ciudad, las razones históricas y los factores geográficos de la concentración espacial de los centros de culto africano en las orillas de estos cursos de agua, que influyó decisivamente en la formación de los suburbios, una vez ubicados en la zona conocida como "Beberibe de Baixo" y alrededores, en el curso de finales del siglo XIX y principios del XX. A la luz de este período, se menciona a los líderes afro-religiosos y sus "terreiros", representados cartográficamente a lo largo del mencionado rio.

Palabras clave: Terreiros de Xangô; Río Agua Fria (Río Beberibe); Formación Territorial; Alrededores; y Recife. 
The text addresses the factors of location of the "terreiros" of Xangô in Recife from the 1930s decade, in an neighboring area of Olinda, the banks of the old Água Fria river (current, channel Vasco da Gama-Peixinhos), tributary of the Beberibe river. It rescues, in the bulge of the North Zone of the city, historical reasons and geographical factors of the spatial concentration of africanreligious centers around these water courses, that decisively influenced the formation of the suburbs of yore "Beberibe de Baixo", and adjacent villages, along the late nineteenth century and first half of the twentieth.

In this sense, to the elucidate the historical and geographical reasons of this formation, this work performs a retrospective of the origin of african-religious cults in the area drained by the Beberibe river, highlighting both the existence of the Quilombo Malunguinho in the woods of Catucá, which had beginning the banks of cited river, as the reports of travelers who recorded the presence of black people surrounding Recife and Olinda, throughout the first half of the nineteenth century. Furthermore, revisits up in the pioneers studies focusing the early indications of Xangô in Pernambuco, that address the links of this religion with the maracatus and frevo clubs in the late nineteenth century.

Moreover, the text focuses its analysis in the transformations occurred in the space of Recife with the advent of the New State (1937-1945), and with it, the process of modernization and "sanitizing" of their central streets and neighborhoods, focused, particularly in the eradication of "mocambos" (shacks), and in the control and repression to homes of Xangô - these expelled to the surroundings of the city. Within this context, this work will show the performance of africanreligious groups of Beberibe de Baixo and surrounding region, which passed to elaborate numerous territorial strategies in order to ensure their practices, dwellings and symbolic places, endowing of meanings the suburbs, and then, neighborhoods in the wake of the territorial formation of Recife.

\section{Where Does the Xangô Live? Location Factors of the Terreiros to the Margins of Água Fria River - Centuries 19th and 20th}

To reflect in the process of Recife's urban expansion, it is necessary to emphasize that in the last decades of the nineteenth century, significant portion of sugar mills situated in the margins of Capibaribe and Beberibe rivers had turned into suburbs or outlying villages (MELO, 1940). With the development of the public transportation, the lands where there were their facilities were being occupied by villages. Which, in turn, would become neighborhoods and suburbs with advancing urbanization in the twentieth century. Not forgetting that with the decline of the sugar economy and 
the advent of mills in more distant locations, the properties of the plain became over the eighteenth and nineteenth centuries, on sites or farms called "arrabaldes" (surroundings or suburbs).

In Andrade's conception (1979), these suburbs consisted in houses of abandoned people, built in the middle of great sites and used to pass the end of year parties. In the suburbs, families had large areas for the cultivation of fruit trees, more ease of water supply, of the rivers for bathing, for medical, for the transport etc.. Privileged conditions for the residents of the "agitated" core city (Recife, São José, Santo Antônio, and Boa Vista), which during the summer months they moved to the surroundings to search mild climate, of quietness, healthier habits or even to treat a disease. Later, however, with the improvement of the communication center-periphery, these "second homes" eventually became permanent residences, with most of these sites located in the floodplains of Capibaribe river: Torre, Madalena, Poço da Panela, Apipucos, Casa Forte... Another small part of lower purchasing power, found itself established on the margins of Beberibe river, having as the main reference the neighborhood of the same name.

Formerly located in Olinda's neighbouring, the suburb of Beberibe was characterized in the second half of the nineteenth century by "remarkable and abundant [...] constructions in sites and buildings, going beyond, however the houses of simple construction, humble, coming hence a large and lively population", recalls Costa (1983, vol. 4, p. 161). These humble dwellings covered by mud clay, and tinfoil waste were conformed in "mocambos", and were occupied mostly by black people and mulattoes (CASTRO, 1968). Their proliferation on the outskirts Recife's is due, among other factors, as the result of the collective transport service development in the city, with the transports to animal traction and trains called "maxambomba"1, which would make the use of the most common and affordable suburbs to the less favored classes. Às more these locomotives were extending their tentacles to other extensions of communication, it stimulated the development of the villages served by them and the ones that were on their way, engendering a kind of "tentacular growth" in Recife. Indeed, journeyed the island centre to the continent, five-way of expansion (North, Northwest, West, Southwest and South), driven both by the suburban roads of steam trains, as by the natural courses of lowland rivers.

Among the villages formed throughout this process were those located at Estrada Nova de Beberibe (current Beberibe Avenue), whose construction started in 1866, and beginning at the

\footnotetext{
${ }^{1}$ Conducted by the company Trilhos Urbanos do Recife a Apipucos, the "maxambomba" drove originally, in 1867, through the surroundings on the banks of the Capibaribe river (Ponte d'Uchôa, Casa Forte, Monteiro, etc.) through the "Caxangá line". Years later, in 1871, with the opening of the line towards Olinda and Beberibe, the locomotive began to serve the settlements located northwest of Recife, toward floodplain of Beberibe. By the year 1922, the maxambombas were used in the city of Recife, being replaced by electric streetcars (SETTE 1978, 1938).
}

Eletronic Magazine: Time - Techinique - Territorry, V.5, N.1 (2014), 23:42 ISSN: 2177-4366 
Encruzilhada, followed by the settlements of Arruda, Água Fria, Fundão Porto da Madeira, to achieve the most prosperous agglomerate of Beberibe. On the banks of this path, amidst hills, streams, mangroves and mudflats, there are multiplied numerous sites and semi-urban settlements, particularly in the area formerly known as "Beberibe de Baixo" (today the neighborhoods of Arruda, Água Fria and Fundão), situated between the lowlands drained by Água Fria river (current channel Vasco da Gama-Peixinhos) and the hills of the Northern Zone of Recife. The initial land division of this region in $1867^{2}$ enabled more rapid occupation in the floodplain of the aforementioned stream, which was already quite populated in the Plant of Recife and its Surroundings, of the 1876 (Figure 01).

The lines and contours of lithography F. H. Carls reveal regular and orthogonal blocks, covering a perpendicular area to the stretch of the current Beberibe Avenue between Encruzilhada and Água Fria, at the junction point between that newly built road, and the Estrada Velha de Beberibe, that started in the address at that time called Cruz das Almas (neighborhood of Tamarineira). The plant layout still allows identifying the Chapel of St. Anthony, built in 1873, and the presence of several shacks scattered in the central streets of the suburban subdivision (streets Machado, Regeneração, José Austregésilo, and of the Moças). Moreover, when observing the detail of the Carl's plant (Figure 01), with framework occupation of Beberibe de Baixo enlarged and enriched by information from other sources ${ }^{3}$, within a temporal cut extended between the years $1876-1924^{4}$, it sees clearly the main elements of peopling in the region, highlighting the mesh of streets and blocks expanded to areas of hills and streams (Alto do Pascoal and Córrego de São Sebastião); to the large number of "mocambos" (shacks); and the presence of two african-religious cult centers, called in Recife as Xangôs ${ }^{5}$.

Furthermore, it is noted in this period, on the other bank of the Água Fria river, the initial occupation of the adjacents villages for the region Beberibe de Baixo: Campo Grande,

\footnotetext{
${ }^{2}$ According to Araújo (2007), the first allotment of lands of the Beberibe de Baixo occurs in 1867, when the Senhorinha Germana do Espírito Santo asked to leave the Board of Olinda to subdivide his property, called Beberibe de Baixo, where she intended to start a settlement. Years later, in 1869, was the division of the neighboring lands of Ranch Agua Fria, owned by Mr. Pedro Sousa Tenório (COSTA, 1981), whose name, was connected to the tributary of Beberibe that drained the region, the Água Fria river.

${ }^{3}$ Menezes (1988), Freyre (1968), Fernandes (1937), and plant of the Department of Health and Assistence of Recife, belonging to the collection of Arquivo Público Jordão Emerenciano.

${ }^{4}$ This time frame is based on the date of elaboration of two plants used: 1876 - Plan of Recife City and its Surroundings (F. H. Carls); and 1924 - Plan of the Department of Health and Assistence of Recife.

${ }^{5}$ According to Gomes Costa (2009), the word Xangô in Pernambuco both caracterize the african-Brazilian religion, facing the Orixá worship (or ancestral deity in african designing), as well as the place where the cult occurs itself, called the terreiro, which happens in the liturgical celebrations called 'toques', which also receives the similar name of Xangô. The term Xangô in the state is polysemic. Since the 1930s, the police and the society never made distinction between the diversity of african-Brazilian religions, always calling all categories of these religions of xangôs, prays umbandas, or catimbós, macumbas, but the term Xangô became more popularized, possibly due to its polysemy, especially among the police repression. Thus, is used in the present work the terminology Xangô such as the major reference for characterizing african descent religions in Recife when discussing these religions and their spaces from the proposed period (1866-1945). However, when the text proposes to examine more specific issues related to Mental Health Service in the 1930s, which saw some terreiros as "low-spiritualism" or "impure" tendencies, will use also, as a way to better clarify the distinctions in terms of social relations, of other terminologies, such as Umbanda, Jurema and Catimbó, that blend to indigenous traditions, Christian and Kadercist, in their cults.
}

Eletronic M agazine: Time - Techinique - Territorry, V.5, N.1 (2014), 23:42 ISSN: 2177-4366 
Encruzilhada, Mangabeira, Tamarineira, and Casa Amarela. In summary, the settlement of these places resulted in the opening of parallel streets along Estrada de Belém's road, and the allotment of sites in Campo Grande; the crossing of paths trod by lines of maxambombas at the Encruzilhada; the physical proximity of Mangabeira regarding the Estrada Velha de Beberibe and the meandering river Água Fria; and of subdivision of properties in Tamarineira and Casa Amarela ${ }^{6}$, within the scope of the advent of steam trains on the Limoeiro's roads and of the Arraial respectively. Moreover, regarding the Tamarineira it is necessary to remember the construction of the Hospital for the Insane of Pernambuco in 1887 (VIANNA, 1970).

However, when analyzing the process of occupation of these suburbs, throughout the end of nineteenth and twentieth threshold, It can be observed a distinct specificity regarding the role played by "people of saint"7, that even in front of a control context and repression ethnicalreligious, elaborated and re-elaborated strategies to organize themselves in the region of Agua Fria creek. From this resistance, the black social groups that sought the maintaining of their practices, homes, and symbolic places, ended up by extending the fabric of the city in marginalized areas by the elite and political-economic instances, redefining the suburbs, and then the neighborhoods.

In light of this process, and seeking to recover the history of these african-religious, it is intended from this moment revisit the past tense presence of the Xangô in the surroundings of the Água Fria's river, reminiscing their leaders and the addresses of their homes. Indeed, dates back even to nineteenth century the first hint of Xangô in the Beberibe de Baixo, with the advent of home Ilê Obá Oguntể, in Estrada Velha de Beberibe (now Estrada Velha de Agua Fria), in the vicinity of the train station Chapéu do Sol. The date of its foundation is inaccurate. According to the oral tradition, the construction of the house began in the last quarter of the nineteenth century, or about one hundred and forty years ago (PEREIRA, 1994). His founder would have been the mother of saint Inês Joaquina da Costa, known as "Tia Inês". At that time, Felipe Sabino da Costa, known as Adão already lived in the house and was the son of the holy yalorixa ${ }^{9}$. After the death of Inês, in 1919, the terreiro - area of religious practice - began to be led by Adão, one babalorixá of extraordinary personality, with a spirit of uncommon leadership to the point of having practically a devotion to her figure (FREYRE, 1968; MOTTA \& BRANDÃO, 2002; FERNANDES, 1937).

\footnotetext{
${ }^{6}$ For example, Costa (1981) cites a notice of the Diário de Pernambuco, 1875, on the sale of sites in Casa Amarela: "site in Arraial, close to Casa Amarella station, afforestation of fruits, low to grass, mud house, tank and "cacimba", excellente water, 2,000 feet from the front "(Diário de Pernambuco, October 26, 1875, p. 6)..

${ }^{7}$ Adherents of afro-brazilian religions.

${ }^{8}$ Currently, the terreiro Ilê Obá Ogunté (or "Sítio de Pai Adão") constitutes one of the most traditional terreiros of Recife, coating of significant importance in the condition of home mother of Xangô of Pernambuco, and african-religious traditions of the city. It is located in the same place of origin, in the Estrada Velha of Água Fria, formerly called the Estrada Velha of Beberibe, presenting as characteristic the orthodoxy, and the nagô ritual his only and constant practice.

${ }^{9}$ Same as mother of saint. Priestess chef of terreiro.

Eletronic Magazine: Time - Techinique - Territorry, V.5, N.1 (2014), 23:42 ISSN: 2177-4366
} 


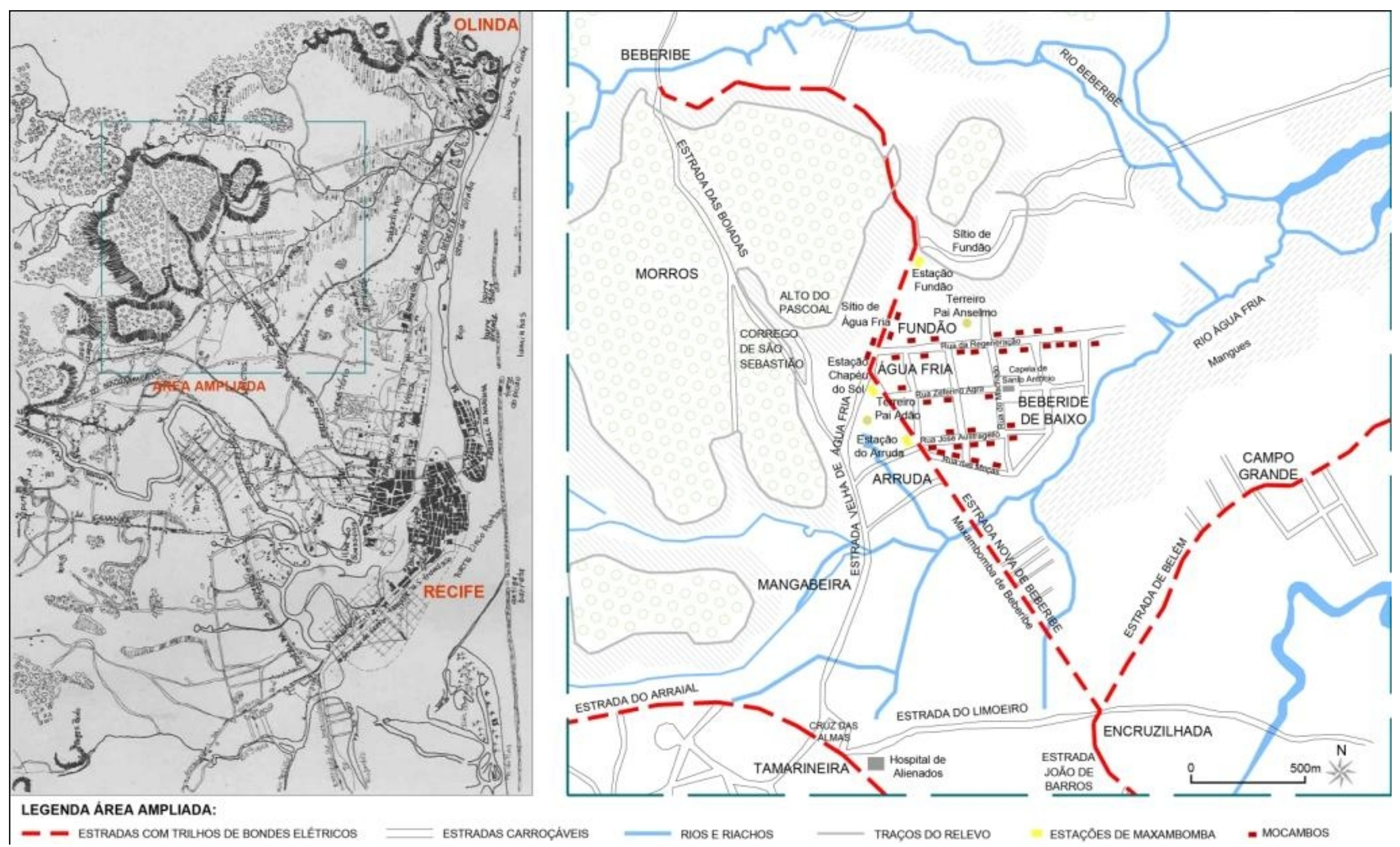

Figure 01: Plan of Recife City and its Surroundings (F.H. Carls) - Detail of the Villages of Beberibe de Baixo (1876) with additional information from the plan of the Department of Health and Medical Care of Recife, 1924 Source: Menezes, 1988. Draft: Bruno Maia Halley / Daniella Burle Loiola.

Eletronic M agazine: Time - Techinique - Territorry, V.5, N.1 (2014), 23:42 ISSN: 2177-4366 
Aside the "Sítio de Pai Adão", there was as one of the first Xango's homes in Beberibe de Baixo, the African headquarters of the father Manuel Anselmo Reis Hipólito. The terreiro of Anselmo, dated between the decades of 1920-1930, was located in the "endless sandy of the Regeneração Street" (FERNANDES, 1937), constituting an afro-religious center of similar expression when compared to the famous terreiro of Adão, and was located "between the houses of clay faraway in mucambaria of Fundão", in the words of Freyre (1968, p. 100). In that place was still found the terreiros of the Círculo Panteísta, father José Amaro; babalorixá Mariano da Silva ${ }^{10}$, the Marcílio Dias Street; and the house of Santo Antônio, in Craveiro Street, which had as its leader mother Maria Celina. Moreover, it was visible in Beberibe de Baixo, the Seita Africana Xambá, of father Arthur Rosendo Ferreira; the Mangerico Street, of father João Nepomuceno Sampaio; and the terreiro of Santana, of the yalorixá Joana Batista (Joana Bode), both in Água Fria. At Arruda, the devoted house to Santa Bárbara, addressed at Moças Street, led by mother Josefa Guedes Pereira (Dona Zezinha), and at the mouth of Água Fria's river, the headquarters of mother Amalia Maria Lima, in Peixinhos' place (CAVALCANTI 1935 and FERNANDES, 1937; FREYRE, 1968; Diário de Pernambuco, 13 Feb 1938).

Besides these referred houses, there was also in the other side of the creek, a significant number of xangôs. In the surrounding hamlet of the Encruzilhada, there was his mother's house called "Velha Rosa", and the terreiros of the patriarch Apolinário Gomes da Mota, and the father of José Gomes da Silva, surnamed "Neri”, apart from father's house Antônio Félix Marinho in place Ilha de João Barros (FERNANDES, 1937; FREYRE, 1968; Diário de Pernambuco, 13/15 Fev. 1938.); and the suburbs of Campo Grande, the terreiros of Maria das Dores (the Santa Bárbara), of the José da Costa (Obaruidá the terreiro), the Oscar de Almeida (Casa de São Sebastião), and the of mother Maria das Dores da Silva (Senhor do Bonfim) (CAVALCANTI, 1935; FERNANDES, 1937). Furthermore, had in the streets adjacent of Estrada de Belém, the terreiro of father José Antônio da Rocha (home Flor do Oriente), Manoel Sirqueira, of Jose Fausto de Oliveira, Heleno M. de Sousa, and Sebastião F. da Silva; beyond the houses conducted by the mothers Lídia da Silva, and Marcionilla Maria da Conceição (Diário de Pernambuco, 13, Fev. 1938). This concentration of terreiros in the 1930s the view Cavalcanti (1935, p 244.), according to which:

\footnotetext{
${ }^{10}$ According to Freyre (1968, p 103): "The terreiro of Mariano is in Fundão of Inside [...] It is a genuine babalorixá. It kills the animals to sacrifice in the most pure ritual. Distributes the meat by children and save the bones for several days in peji. Dances and authentic styles".
} 
most african sects are located in the marginal lines of Beberibe and Campo Grande, which are poor suburbs of the city. Encruzilhada, Água Fria, Arruda, Chapéu do Sol and Fundão, in all these places are found terreiros. Terreiros of nagô cult, gege, xanhá predominantly of nago.

The affirmative of Cavalcanti resembles with Fernandes (1937, p 20.): "Occupy, as it sees, distant streets of suburbs away from the city center, whereas in the zone corresponding to road of Beberibe and Campo Grande are at mostly these terreiros [...] ". However, it is important to note that this concentration of xangôs in Beberibe de Baixo and surroundings (Campo Grande and Encruzilhada) also extended at the time to the outskirts of Mangabeira and Casa Amarela, along the aforementioned Água Fria river (a tributary of the Rio Beberibe), stronghold of the broader succession of xangôs known in Recife of yore. Therefore, in Mangabeira, beside the Arruda, there were the terreiros of the Navegantes, of the father Severino Bezerra, and the house of São Jerônimo, which had as leadership the patriarch José Cláudio de Almeida (CAVALCANTI, 1935; FERNANDES, 1937). At Casa Amarela, included the presence of two african-religious centers: the one of father Janio José Chagas; and mother Guida (or Idida) F. Mulatinho (Diário de Pernambuco, Feb. 13, 1938).

Leaving the xangôs radius of the Água Fria river, there were still other terreiros along the plain Recife, three along Beberibe's river - one in Porto da Madeira, at Joaquim Portela Street, father Arthur Alves, another one in Salgadinho (Olinda), the one of mother Maria L. de Almeida, and another one in Santo Amaro, in the terreiro of Manoel M. da Silva; five along the Capibaribe river - two in the Várzea (place Bomba Grande), the one of the mother's Maria Joana Anunciada and Baiana Joana, one in the Iputinga, one of father Tibúrcio Braga, one at Cordeiro, one of Virginia da Conceição, and one in Afogados, whose leader was that had as leading the mother Alayde Maria do Carmo (FREYRE, 1968; BRANDÂO, 1988; Diário de Pernambuco, 13 and 15 Feb., 1938); other two terreiros were situated on the banks of Tejipió river at in the village of Totó: the São Jorge african center, of the leader Lucio Alves Feitosa (the popular "Paisinho"), and the terreiro of Santa Bárbara, led by João de Deus da Silva (BRANDÃO, 1988; Diário de Pernambuco, 13 Feb., 1938; LIMA, 1937). And finally one terreiro was established in the lands drained by the Pina basin, represented by mother "Preta Fortunata", also known as "Baiana do Pina" in the past (FERNANDES, 1937). 
Besides these mentioned priests, still were possible to identify, in the ongoing research $^{11}$, the existence of over 10 african-religious leaders in Recife '30s ${ }^{12}$, from the crossing-references contained in studies of Freyre (1968), Brandão (1988), Cavalcanti (1935), Fernandes (1937), Lima (1937), Alvarenga (1948), and editions of the Diário de Pernambuco 13 and February 15, 1938. However, in the consulted sources, there is no reference about the terreiros of these leaders, neither their addresses, but only evidences of a distant position effectively secure to the registry and location of these xangôs in this text.

On the other hand, it is noteworthy that 40 of the terreiros listed here (with the names of xangôs and their religious leaders), a number of 29 were located in the vicinity of Água Fria river, and the other 3 were identified on the banks of Beberibe river (Figure 02). Revelating numbers both of a concentration of xangôs from this region of Recife and Olinda, as an importance attached to these centers, objects of studies published at that time, mostly by doctors and intellectuals involved with the Service Mental Health of Pernambuco (S.H.M). Body established in 1932, in the context of ethnic and religious persecution to the africandescents, which the main objective was focused on knowing, controlling and differentiating the traditional xangôs, these understood as reminiscent of african religion, and catimbós (impure xangôs) understood as a moral perversion or quackery (FRANÇA LIMA, 2005; BRANDÃO, 1986).

In face of these principles, the S.H.M. had the advise of fathers and mothers of holy of lineage considered "pure" to verify the existence of charlatans, deemed without "competence". It should be noted that some of these leaders, interested on seeking the police protection, and, at the same time, freedom to their religious practice, not only invited the members of this service to watch their "touches", but also denounced those seen as "incompetents" (FERNANDES, 1937). This practice engendered a network of intrigue between xangôs, enabling to technicians of S.H.M. a bigger approximation with the "pure" and mystified terreiros, especially in the midst of the Água Fria river $^{13}$ houses, which were adjacent to the headquarters of the service, once installed in the building of the Hospital for the Insane of Pernambuco, in Tamarineira. Such proximity ended up establishing an intense

\footnotetext{
${ }^{11}$ Doctoral research in progress of the text author in the Programa de Pós-Graduação in Geografia, Universidade Federal Fluminense, which is provisionally called City-Venice x City-Catimbó: Spaces of Control and Territorial Strategies African Religious in the Recife of yore (1866-1945).

${ }^{12}$ Babalorixás: Luiz José da Silva, Honorio Rodrigo Chaves, Antônio Sampaio, and José Soares da Silva; Yalorixás: Josepha Maria da Soledade, Elisabeth de França Ferreira, Severina Maria da Conceição, Philomena Maria da Conceição, Gerladina Torquato Braga, and Josepha da Silva.

${ }^{13}$ In the past, had as examples of "purê" Xangôs in Beberibe de Baixo, the Sítio de Pai Adão and the terreiro of Anselmo, and unclean "terreiros", the Seita Africana de Josefa Guedes Pereira (FERNANDES, 1937).
} 
relationships exchange, influencing on the achievement of the 1st Afro-Brazilian Congress in 1934, in Recife, jointly organized by the Beberibe de Baixo priests and intellectuals of S.H.M., which the opening happened at the Anselm's Xangô, in the suburbs of Fundão (GUILLEN, 2005).

However, when the emergence of the New State policy (1837-1945) in Brazil, and particularly in Pernambuco, decreed an ordinance in 1938 by prohibiting the operation of african-religious centers in Recife. The justification for this measure focused in the idea that these places constituted spaces of people degradation, which conformed one segregated and racist policy, considering that this action hit directly the afrodescendants groups of the city. Henceforth, it was intensified the control and repression of black people, especially the adherents of the Água Fria river Xangô, at the time the most monitored and known terreiros by the police and S.H.M.. No wonder, these were the first centers to be closed, along with others cited here, with the advent of the ordinance $1938 .{ }^{14}$

The prohibited xangôs list of working added with the terreiros listed in the studies of the season allows some considerations about these cults in Recife of 1930: 1) The criterion used by scholars to identify the xangôs were much more of the houses expressiveness, and of the coexistence and familiarity with the saintly fathers, associated to a greater control over the houses because the physical proximity to the S.H.M.. So, the existing samples are far of being accurate as the number of these centers, since, even in the 1930s, the city has certainly had a bigger number of these. 2) According to the submitted informations, there is no registry of headquarters in the center of Recife or in the neighborhood. This suggests that the number of terreiros were bigger. On the other hand, the strategies of african-religious to escape from the police chases, with its countless guises, prevented accurate quantitation of the terreiros and make impossible the record of the existence of these in the central area, which, in turn, eradicate their shacks and mocambos, by expelling african-religious centers to the outskirts of the city; 3) The xangôs presented as a common feature the fact that these are located preferably in the suburbs, especially those occupied by the lowest economic population and social level (RIBEIRO, 1978), commonly living in shacks erected within the topographical conditions of the geography of Recife (Figure 03): be in high areas (high and hills), or be in marshy areas (streams and wetlands), along the plain rivers.

\footnotetext{
${ }^{14}$ About the first african-religious centers prohibited of operation, notes up the matter content of Diário de Pernambuco, 1938: FECHADOS pela polícia vários xangôs. Diário de Pernambuco, Recife, 13 de fev. 1938. Arquivo Público Estadual Jordão Emerenciano (APEJE).
} 
Still about this last consideration, it adds that the characteristic picture of Xangô appears to date back to the early years of colonization, considering especially the history of the black people presence in the North Zone of Recife. About this, Brandão (1988) ensures that "the surrounding neighborhoods of the Beberibe river are appointed since the seventeenth century as a redoubt of poverty and people of color. This fact indicates that this area (which includes the Encruzilhada) forms one of the oldest niche of xangôs location in Recife". In this perspective, despite the scarcity of records on this Brandão assertion, it becomes possible to deduce the former presence of xangôs in floodplain of Beberibe from the reports found in the Anais Pernambucano, from Francisco Pereira da Costa. In these Anais, there is a reference to the existence of the Irmandade de Nossa Senhora da Boa Hora, in the village of Beberibe, in 1787. It was a congregation composed by "colored men", free or slave, who erected in the village church an altar to their patroness, which annually celebrated their festivity. According to Costa (1983, vol. 6, p 45/46): "The feasts of Nossa Senhora da Boa Hora [...] proceeded of its competent novenario, were famed, competitive, until they disappeared with the passage of time, as one of many other of equal pompous accents". Perhaps the presence of this congregation is a proof of the religious syncretism of that time; an indicative of africanreligious manifestations of the black population of the Beberibe river in the slave context of the eighteenth century.

Another important record, dated from the second decade of the nineteenth century, concerns the existence of Quilombo de Malunguinho, in the forests of Catucá, which began in the thickets and hills of Recife and Olinda, in the stretch drained by the Beberibe river, extending to the north towards the villages of the Macacos, Cova da Onça and Paratibe. It is was situated, therefore, in an area beyond the agricultural frontier of the North Forest Zone, including all the forests where they lived aquilombados black people from Recife to Goiana, once, the second largest town of the province, near the border with the state of Paraíba (Figure 04). This Quilombo was divided into scattered groups through the woods who acted jointly or separately, as needed to dictate the moment needs seated in the multiple survival strategies and slave resistance (CARVALHO, 2011). 


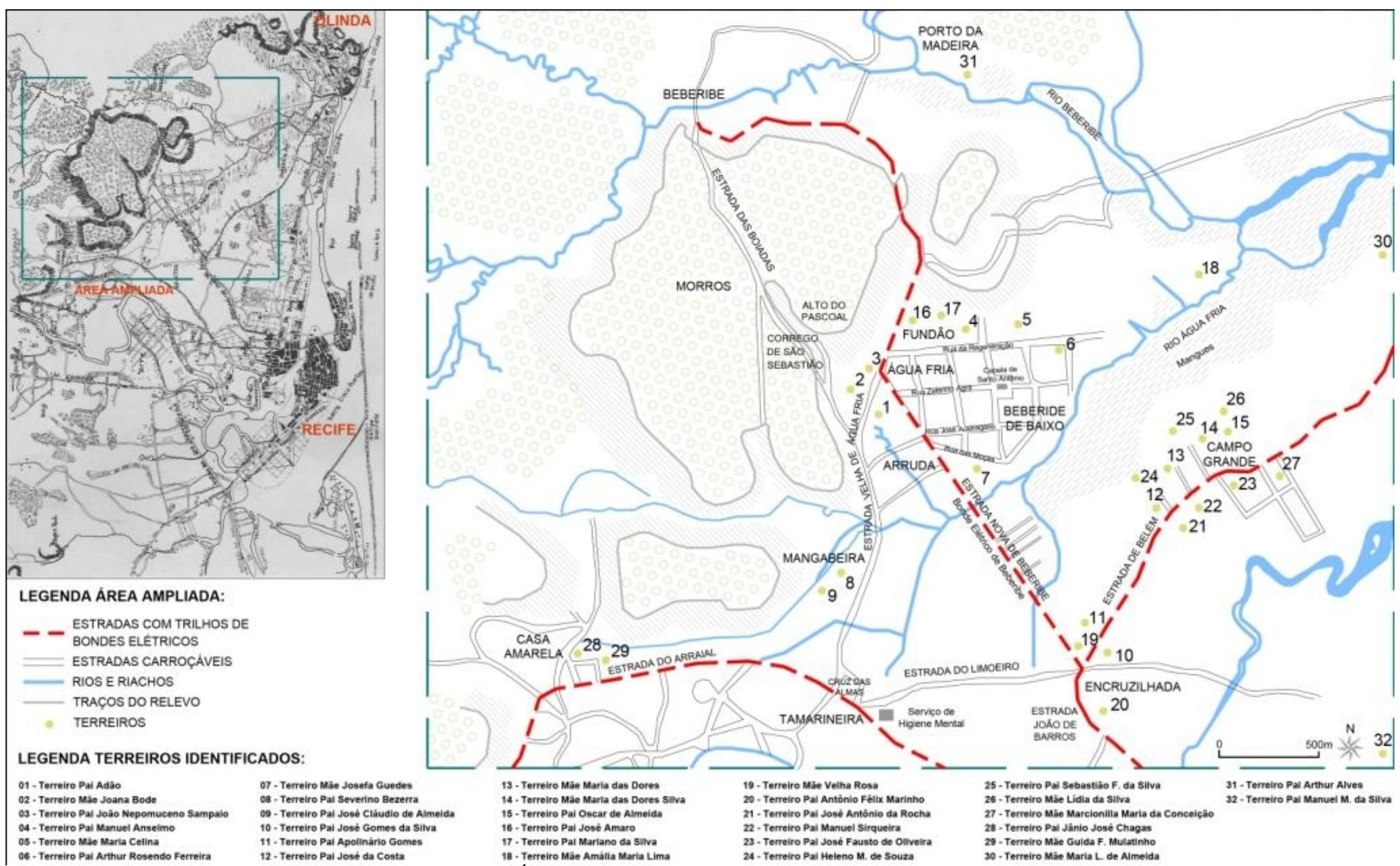

Figure 02: Detail of Xangôs Location of the Environs of Água Fria River- 1930 - (Plant of Recife and its Surroundings 1876). Source: Menezes, 1988; Lima, 1937; Fernandes, 1937; Cavalcanti, 1935; and Diário de Pernambuco 1938. Draft: Bruno Maia Halley / Daniella Burle Loiola.

Eletronic Magazine: Time - Techinique - Territorry, V.5, N.1 (2014), 23:42 ISSN: 2177-4366 


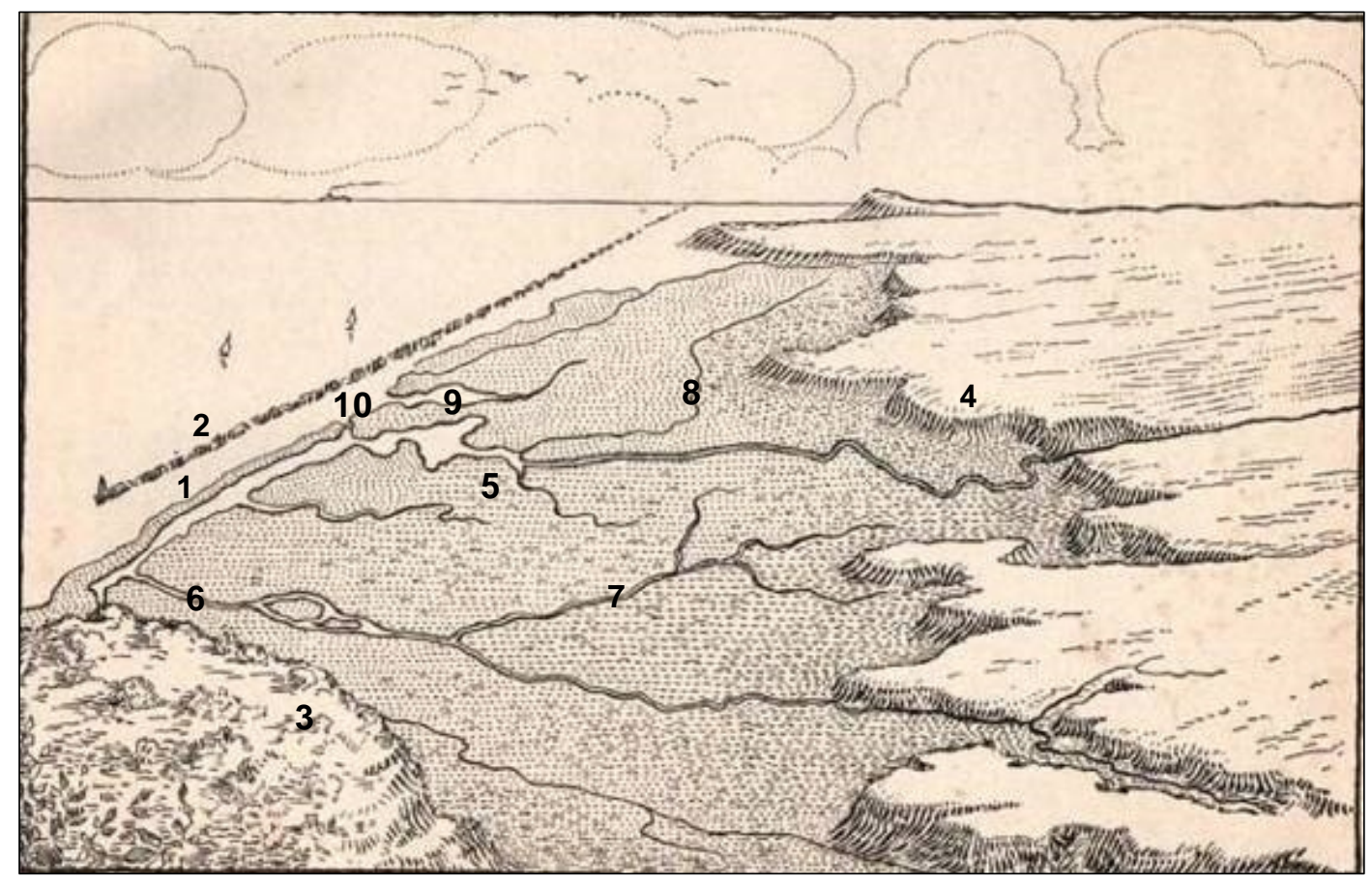

Figure 03: Urban Primitive Site of Recife (Bay Crammed of Recife by J. C. Branner) - the coastal cordon (1), the coastline of reefs (2), the hills of Olinda (3), the hills of Jaboatão (4) Capibaribe river (5), Beberibe river (6), Água Fria river (7), Tejipio river (8), Pina basin (9), Estuary of Rivers (10). Source: Castro (1954).

In light of this context, it is believed that the escape route of slaves began in the northern forests of Recife, on the border with Olinda, on the banks of Beberibe river, where calm waters showed navigable throughout its length (CARVALHO, 2011; CABRAL DE MELLO, 1992). This condition allowed the frequent use of canoes in the communication between the two cities, even among the slaves, who certainly started the road map of their leaks through the mentioned river by following this until reach the woods of Catucá. It is a Historical fact that corroborates the analysis of the reasons of the Xango's concentration in the Beberibe zone in the first half of the twentieth century, and, therefore, its tributary, the Agua Fria river, which also had featured conditions of seaworthiness in its path (MELLO, 1992). This characteristic probably motivated the occupation of its banks, through the mangrove landfill accomplished either by "mocambeiros" as by afrodescendants of Xangô, who had settled there much because of the historical connection of their ancestors (slaves) with the lands drained by the Beberibe river. This becomes evident when it observes nowadays the songs of 
terreiros ${ }^{15}$ from this region, focusing on evocations to "King Malunguinho" entity of a big relevance in the religions of the Pernambuco's orixás:

There is only one in the forest, it's the King

The King of the Forest is Malunguinho.

Yes I steadied my point

Yes I did in the middle of woods

Yes Save the crown

King Malunguinho.

Another interesting piece of information in understanding of the historical presence of black people in the Beberibe region regards the reports of travelers who visited the cities of Olinda and Recife in the first decades of the nineteenth century. Although these records do not mention the existence of religious manifestations among black people, by deduction it can be imagined the presence of these, especially the densely villages occupied by "men of color", where there are valuable descriptions about slavery, its forms of occupation and housing. For example, the French traveler Tollenare (1978, p 22) describes in his diaries the following notes about the village of Beberibe:

Leaving Recife passes by the village of Beberibe, situated on the river of the same name, adorned by beautiful villas; where it washes most of the clothing of Recife, where there is no fresh water. [...] All this space is well populated by Brazilians, mulattos and free black people: the houses and gardens succeed within walking distance.

The report of Tollenare shows the importance attached to the outskirts of Beberibe in the past Recife of the past, which since ancient times that it was constituted to bastion of blacks, that sought permanent housing in the most distant places, in search of a more suitable space to build their "mocambos" (shacks), to exercise their riverside activities (laundry, boating, carpentry etc.), and, certainly, for the celebration of their worship and african-religious rituals. Furthermore, as alluded earlier, it was conformed to the region of Beberibe in a strategic territory of slave resistance, threshold trail of rebellious black people, who were concentrated in the forests of Catucá, taking refuge from the control and repression of hegemonic groups of the time.

\footnotetext{
${ }^{15}$ See these songs in: MOTTA, R. Jurema. Recife: Massangana, 1988.; PINTO, C. M. Saravá Jurema: as várias faces de um culto mediúnico. 1995. Dissertação (Mestrado em História) - Centro de Filosofia e Ciências Humanas, UFPE, Recife.
} 


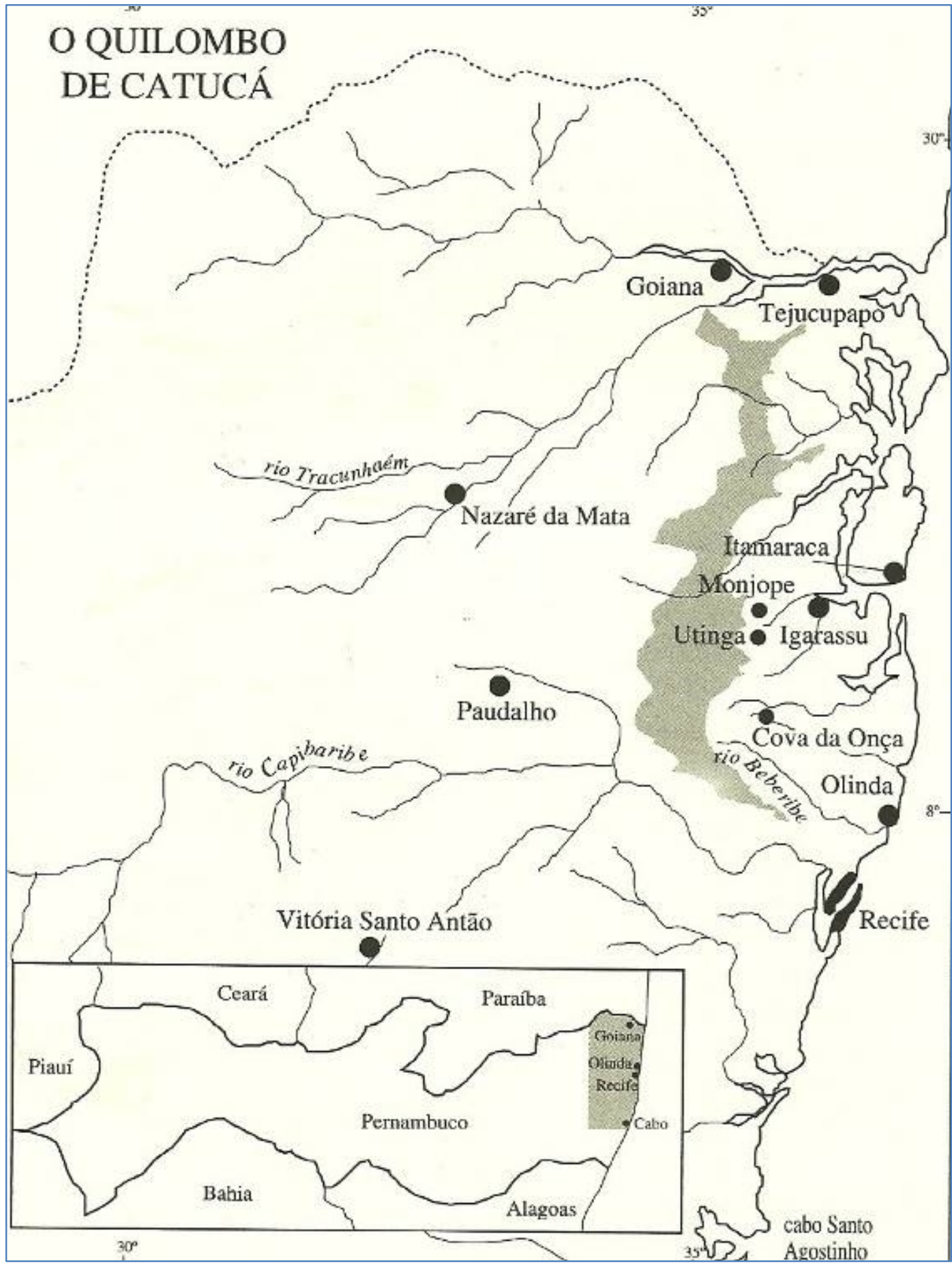

Figure 04: Location of the Quilombo Malunguinho at the Matas de Catucá in the North Forest Zone of Pernambuco - Home of the Slave Resistance in the Margins of Beberibe River, between the cities of Recife and Olinda. Source: Carvalho (2011).

Aside from those indicated evidence about the origin of black people in the Beberibe river, it is worth highlighting the record of René Ribeiro (1978) who cites information about the beginning of the Xangô in the Recife from an engraving of Eletronic M agazine: Time - Techinique - Territorry, V.5, N.1 (2014), 23:42 ISSN: 2177-4366 
number 105 from the Zoobiblion, of Zacharias Wagner, who had visited Pernambuco between the years 1634 and 1641. In his wanderings in the territory, Wagner is impressed with the celebrations of the slaves, and, from his description of this "black dance", of figure 105, Ribeiro (1978, p. 29) comes to the conclusion that it was a "wheel of Xangô", because

[...] The same circle of dancers moving to the left with attitudes characteristic choreographic; identical position of the ogan-ilu touching two drums of the common type across West Africa and one agogô; the jar of garapa next to the drummers; the same position and attitude of the priest.

In another part of his text, Ribeiro (1978) highlights the existence of xangôs in Recife in the second half of the nineteenth century, describing the address of active centers in the central neighborhood of São José and surroundings. Although not cite the sources of this statement the author assures:

[...] Located in São José neighborhood in the Calçadas Street, of Pescadores, of São João, the Gasômetro, and Campina do Bode; others were in Boa Vista, in Aldeia of 14, and Estância - where Henrique Dias had erected a votive chapel (RIBEIRO, 1978, p 36.).

According to Brandão (1988), what can be found from that time are the records about maracatus. Celebrations formed by "groups of descendants organization of black Africans from the past centuries" (REAL, 1977, p. 67). Of these, the Elefante, founded in 1800, and the Leão Coroado in 1863, are among the oldest. Among the features of these amusements are the choice of "people of color", and that they tend to have a closer link with the cults of Xangô, especially the nagô influence, as shown by Real (1977). Not coincidentally, Ribeiro (1978) have pointed that another hypothesis of the embryo of Xangô would be the maracatus, seen as remnants of the institution of the kings of Congo.

From late nineteenth century, it is known know information regarding the advent of frevo clubs and mockeries right after the abolition of 1888, and that gathered mostly black. ${ }^{16}$ With the loosening of the slave system, these people ends up doing humble functions which passed to designate the name of their carnival associations (Blacksmiths, Mops, Craftmen, shakers, loggers etc.), keeping them financially through their earnings, and, certainly, the cults performed there. Unfortunately, whether there is

\footnotetext{
16 "From all the clubs, the oldest is the Vassourinhas, founded in 1889, and the Pás de Carvoeiro, founded in 1890. From the "troças", the oldest is the Man of the Cachorro do Miúdo, founded in 1910" (BRANDÃO, 1988, p 118).
} 
information about the location of the many forms of carnival groups (maracatu, frevo and mockeries clubs), the same can not be found related to the location of the xangôs. However, it can be deduced from the words of Brandão (1988), that some of these cults could have as a headquarters his own association, or could be located in neighborhoods (the example of São José) where there were other associations, or indeed in the neighborhoods or suburbs where black people and their descendants lived.

In this sense, between the late nineteenth century and the threshold of the twentieth century, it is supposed that there were some carnival groups in the area of the Beberibe de Baixo's mocambos and vicinity, and that they also served as a space for celebrations of african-religious cults. From the 1930s, however, there is the certainty of this presence along the Agua Fria river, and that these associations have multiplied due to several factors: urban reforms of the central neighborhoods, which resulted in the territorial displacement of the associations, mocambos and terreiros to the surroundings of Recife (COSTA GOMES, 2009; FRANÇA LIMA, 2005); the arrival of migrants who brought with them the customs and practices of the Northeast interior popular culture of the city northern zone; and strategies of african-religious groups that camouflage their xangôs in carnival groups as a way to circumvent the control and repression of the hegemonic groups from that time (COSTA GOMES, 2009).

Meanwhile, it is necessary to emphasize that these processes were underlying to the political, economic and social context, of that time, which was marked especially by the abolition of slavery, and the decline of the sugar economy, which entailed the migration flow from the countryside to Recife. Moreover, the most new roads opening and transport development, with the advent of steam trains, finally led to enable a faster occupation of the suburbs, and with it the proliferation of mocambos and terreiros. The consolidation of this "suburb democratization of Recife" (MELLO, 1992) occurs from the second decade of the twentieth century with the arrival of the even more accelerated poor population to the city, who were settled in areas of the hills, this time also coming from the mocambos existing in the center flooded area, and that once served as shelter for the marginalized, to the free men of the sugar zone and the victims of the Sertão of famine. ${ }^{17}$ Henceforth, this framework of occupation intensifies in the following decades

${ }^{17}$ The occupation of the hills of the Northern Zone, more particularly in the high Água Fria, began in the 1920 decade, as can be seen in the plant of the Department of Health and Assistence, of 1924, highlighted here in detail in Figure 01 of the text. 
(1930-40) with the rapid arrival of migrants to the outskirts of the city, stimulating the conformation of the continuous urban mass of Recife.

\section{Endnotes: Territorial Strategies of African Religion to the Margins of Água Fria River}

As noted, from the advent of the New State regime, the city of Recife witnesses profound changes in their tissue engendered by the introduction of urban reforms based in the modernization and "sanitization" of the central districts, which had, among other objectives, the eradication of hovels, and the control and repression of african-religious centers. In light of this context, the adepts of african-Brazilian religions of Água Fria river eventually develop and redevelop territorial strategies giving the control and repression ethnic-religious of that time.

Thus, in order to prevent the closing of their terraces, the afrodescendants groups disguised their headquarters in Kardecists centers or in carnival groups, or even disguise their african ancestors and deities behind the Catholic saints. These mechanisms allowed the guarantee of housing, work, and leisure, apart from conducting religious practices marginalized by hegemonic groups of the time. Moreover, these tactics allowed

Rebuild the social networks and negotiations that were created and (re) created around these terreiros, sometimes by repeatedly displaced, sometimes fixed, with the aim of ensuring their religious practices, and in some cases even helping with the process of occupation/housing of the locality where were fixed in the most distant geographical areas away from the police persecution (GOMES COSTA, 2009, p. 26).

In these places, especially in the suburbs of Beberibe de Baixo and vicinity, the members of the xangôs found themselves imbued by a sense of territoriality (SACK, 2011; HAESBAERT, 2004), searching through their strategies, a territorial control as a way of continuing their cultural practices, once condemned by the dominant structures. Through this resistance, the afrodescendants reframed the spaces in Recife's geography, marked by the simultaneous presence of a Venice-City, desired by the elite and rulers of that time, and a Catimbó-City, stronghold of the subalterns of Água Fria river.

In the work presented it was described the historical reasons and factors of the location of the Catimbolândia, characterized by the strong presence of xangôs in the context of the it's surrounding suburbs to the creek mentioned. The incursion by mapping these terreiros, identifying their respective leaders in Recife from the 30s of 
the last century, was aimed to elucidate the initial formation of the present neighborhoods of Arruda, Água Fria, Fundão, Casa Amarela, Encruzilhada, Campo Grande and Beberibe. This revisitation was centered within a delimited historical period (the late nineteenth and early twentieth), marked by the presence and resistance of the afrodescendant groups, which were decisive for occupation and expansion of the North Zone of city.

\section{References}

A CAMPANHA CONTRA OS “XANGÔS" - Novas apreensões de material. Diário de Pernambuco, Recife, 15 de fev. 1938. Fundação Joaquim Nabuco.

ALVAREGA, O. Registros sonoros do folclore musical brasileiro. São Paulo. Departamento de Cultura, 1948 - 3 vols. (Vol.1 - Xangô).

ANDRADE, M. C. Recife: problemática de uma metrópole em região subdesenvolvida. Recife: UFPE, 1979.

ARAÚJO, R. de C. B. de. As praias e os dias: história social das praias do Recife e de Olinda. Recife: Fundação de Cultura Cidade do Recife, 2007.

BRANDÃO, M. do C.; MOTTA, R. Adão e Badia: carisma e tradição no Xangô de Pernambuco. In: SILVA, Vagner Gonçalves da (Org). Caminhos da alma: memória afro-brasileira. São Paulo: Summus, 2002.

. “A localização dos xangôs na cidade do Recife". In: Revista Clio, n. 11, p. 117-135, 1988 (Série História do Nordeste-UFPE).

. Xangôs tradicionais e umbandizados do Recife: Organização

Econômica. 1986. Tese (Doutorado em História) - Faculdade de Filosofia, Letras e Ciências Humana - USP. São Paulo.

CABRAL DE MELLO, E. “Canoas do Recife”. In: MAIOR, M. S. \& SILVA, L. D. da. O Recife - Quatro séculos de sua paisagem. Recife: Editora Massangana,1992.

CARVALHO, M. J. M. de. "O quilombo de Malunguinho, o rei das matas de Pernambuco”. In: REIS, J. J. \& GOMES, F. dos S. (orgs.). Liberdade por um fio: história dos quilombos no Brasil. São Paulo: Companhia das Letras, 2011.

CASTRO, J. de. Documentário do Nordeste. São Paulo: Brasiliense, 1968.

A cidade do Recife - ensaio de geografia urbana. Rio de Janeiro: Casa do Estudante do Brasil, 1954.

CAVALCANTI. P. As Seitas Africanas do Recife. In: Estudos afro-brasileiros. Rio de Janeiro, Editorial Ariel, 1935.

COSTA, F. A. P. da. Anais pernambucanos. 2. Ed. Recife: FUNDARPE, 1983. v. 1, 4 e 6 .

1981.

. Arredores do Recife. Recife: Fundação de Cultura da Cidade do Recife, 
FECHADOS pela polícia vários xangôs. Diário de Pernambuco, Recife, 13 de fev. 1938. Arquivo Público Estadual Jordão Emerenciano (APEJE).

FERNANDES, A. G. Xangôs do Nordeste: investigações sobre os cultos negrofetichistas do Recife. Rio de Janeiro: Civilização Brasileira, 1937.

FREYRE, G. Guia prático, histórico e sentimental da cidade do Recife. Rio de Janeiro: José Olympio Editôra, 1968.

FRANÇA LIMA, I. M. de. Maracatus-nação, ressignificando velhas histórias. Recife: Edições Bagaço, 2005.

GUILLEN, I. Xangôs e maracatus: uma relação historicamente construída. Ciências Humanas em Revista, São Luiz, V. 3, n. 2, dez. 2005.

HAESBAERT, R. Território e territorialidade - um debate. In: Revista Geographia, Rio de Janeiro, Vol. 9, n. 17, p. 19-46, 2007.

LIMA, V. Xangôs. Recife: Empresa do Jornal do Commércio, 1937.

MELO, M. L. de. Pernambuco: traços de geografia humana. Recife: Gráfica Jornal do Commércio, 1940.

MENEZES, J. L. M. Atlas histórico cartográfico do Recife. Recife: Massangana, 1988.

MOTTA, R. Jurema. Recife: Massangana, 1988.

PEREIRA, Z. D. O Terreiro Obá Ogunté: parentesco, sucessão e poder. 1994.

Dissertação (Mestrado em Antropologia) - Centro de Filosofia e Ciências Humanas, Universidade Federal de Pernambuco, Recife.

PINTO, C. M. Saravá Jurema: as várias faces de um culto mediúnico. 1995.

Dissertação (Mestrado em História) - Centro de Filosofia e Ciências Humanas, UFPE, Recife.

QUEIROZ, M. R. F. Religiões afro-brasileiras no Recife: intelectuais, policiais e repressão. 1999. Dissertação (Mestrado em História) - Centro de Filosofia e Ciências Humanas, Universidade Federal de Pernambuco, Recife.

REAL, K. O folclore no carnaval do Recife. Recife: FUNDAJ, 1977.

RIBEIRO, R. Cultos afrobrasileiros no Recife. Recife: MEC/Instituição Joaquim Nabuco de Pesquisas Sociais, 1978.

SACK, R. O Significado de Territorialidade. In: DIAS, L. e FERRARI, M. (Org.) Territorialidades humanas e redes sociais. Florianópolis: Insular, 2011.

TOLLENARE, L. F. de. Notas dominicais. Recife: SESC/Departamento de Cultura. 1978. (Coleção Pernambucana, 1 fase, 16). 